\title{
CINEMA
}

\section{Cinema em 2004}

Em 2004, a indústria cinematográfica mundial gerou grande quantidade de filmes; porém, aos olhos de muitos críticos, poucas dessas obras seriam de qualidade superior. Neste ensaio, Lucas Rodrigues Pires, historiador e colunista do Digestivo Cultural, comenta esse quadro e analisa os melhores filmes de 2004, aqueles que deveriam merecer lugar de destaque entre as opções dos espectadores e nas antologias cinematográficas.

ano de 2004 não foi de grande vulto qualitativo para o cinema. Se pensarmos que em um ano são exibidos nas telas brasileiras aproximadamente 250 novos filmes, podemos dizer que al go em torno de $10 \%$ deles são dignos de nota. Claro que para al guns (aqueles amantes do san- gue, perseguição e efeitos especiais do cinemão americano) o número de bons filmes será maior, mas aqueles de gosto apurado, apreciadores do sabor doce e delicado que só um belíssimo filme pode oferecer, viu uma fatia reduzida deles.

0 cinema brasileiro independen- te foi capaz de nos brindar com alguns el ementos singulares em sabor, três em especial: Narradores de Javé, De passagem e o documentário 0 prisioneiro da grade de ferro. As ficções são produções paulistas, a primeira ambientada no Nordeste, enquanto a segunda se passa quase todo no 
metrô e no trem paulistanos. $\mathrm{N}$ arradores de Javé evoca a época dos contadores de "causos", uma forma popular de falar da história oral. Para escrever a grande história de Javé, os moradores da pequena vila são ouvidos por Antônio Biá, o único capaz de transformar uma história contada em história escrita. A diretora Eliane Caffé mostra que a história como ciência da verdade pode ser falível, pois, como todos querem a glória de fazer parte da história, os relatos dos habitantes se mostram exagerados, parciais. 0 maior trunfo do filme está na presença de José Dumont, que cria um personagemsíntese do brasileiro, Antônio Biá, já marcado definitivamente como dos grandes do cinema brasileiro.

Já D e passagem, de Ricardo Elias, conta a história de três garotos em dois tempos - quando crianças e no fim da adolescência. 0 presente traz 0 assassinato de um deles, o que vai unir os outros dois na cruzada pelo reconhecimento do corpo, localizado no outro lado da cidade. A narrativa presente é norteada pela do passado, quando os três estiveram em situação similar, cortando São Paulo para fazer uma entrega de um traficante. Ambos são um rito de passagem aos jovens.

0 prisioneiro da grade de ferro documenta o Carandiru antes de ser desativado. Feito com câmeras digitais, boa parte das cenas vistas foram captas pelos próprios presos, numa oficina de cinema realizada pelo diretor Paulo Sacramento (daí o subtítulo Auto-retratos). Prisioneiro põe em xeque a própria estrutura

Pratos mais politizados também fizeram parte do menu de 2004. O maior deles veio de um típico nerd americano, Michael Moore.

documental ao reconstruir o presídio num truque de edição da imagem de sua demolição. Ensinou Eisenstein que o cinema é feito na montagem, na colagem de planos. Sacramento articulou e colou imagens feitas pelos presos, mas impôs sua visão a elas. São histórias fabulosas, vidas dilaceradas, um mosaico que expõe, como poucas obras, a tragédia brasileira que é a injustiça social.

\section{Indústria brasileira nascen-}

te. Associados ao aparato de marketing da Globo Filmes, Olga e Cazuza 0 tempo não pára são experiências mais industriais. Foram pratos feitos com os mais ricos e cultuados ingredientes, mas de resultados distintos. Jayme Monjardim, o diretor de novelas, privilegiou o gosto medíocre em detrimento do sabor excepcional que seus ingredientes ofertavam. Encheu Olga de planos e contraplanos pobres, situações melodramáticas excessivas, acompanhadas de música grandiloqüente. Apesar disso, teve ótimo público. Mas, para o diretor, como declarou diante das críticas, é o que importa e basta.

Em contrapartida, Cazuza, parceria de Sandra Werneck e Walter Carval ho, rendeu melhor sabor. Uma pitada certeira na reconstrução dos anos 80 imprimiu ao filme a necessária sensação da geração libertária pós-ditadura, do clima de sexo, drogas e rock'n'roll. Essa parcial biografia do cantor e compositor fez, acertadamente, um retrato do jovem Cazuza sem mascarar certas excentricidades do personagem nem sua homossexualidade.

Pratos mais politizad os também fizeram parte do menu de 2004. 0 maior deles veio de um típico nerd americano, Michael Moore. Ele marcou seu nome na recente história americana como aquele que teve coragem de peitar deliberadamente George W. Bush. Fahrenheit 11/9 é uma extensa pesquisa do cineasta para provar que 0 atentado terrorista de 11 de setembro em Nova York ocorreu por omissão do presidente Bush, pintado como um cowboy boçal, além de incompetente e preguiçoso. Um filme que, exagerado ou não, se fez necessário. $\mathrm{E}$ Cannes entendeu isso ao dar-Ihe a Palma de 0 uro.

Dentro e fora do Brasil. No mesmo viés político, mas não panfletário, bebeu Walter Salles ao filmar Diários de motocicleta, sobre a viagem pelo continente latino-americano do jovem Ernesto Guevara, aquele que viria a ser o revolucionário Che Guevara. Então estudante de medicina, ele e o amigo Alberto saíram de moto para explorar o conti- 
A questão é saber escolher qual filme ver. Encare um prato nacional sem marketing, abra a mente para um europeu mais ousado, sem esquecer os bons diretores americanos que ainda persistem.

nente e encontraram a solidariedade de um povo marcado pela miséria. Se seu diretor evita cair no discurso do revolucionarismo que marcaria Che dali pra frente, acertadamente brota a semente de que a revolução nasce de uma situação de injustiça e miséria.

Grandes autores sabem que 0 valor de uma obra está em reconhecer ali um artista. E 0 autor modelo da pós-modernidade é Quentin Tarantino, 0 amante de filmes B e de sangue espirrando por todos os lados. Seu Kill Bill, contado em duas partes, uma história de vingança das mais inverossímeis, é puro Tarantino do início ao fim. Citações a seus mestres (filmes de samurai, os faroestes de Sergio Leone), diálogos criativos e ótimo repertório musical ainda fazem dele um cineasta autoral, coisa que também se pode dizer do mexicano Alejandro González Iñárritu, que, dizem, segue os motes do cinema tarantinesco. Depois do festejad o A mores brutos, acabou convocado para filmar em Hollywood. Dirigiu 21 gramas com sua reconhecida qualidade de filmar a corrosão interna de seus personagens, dilacerados pela presença constante da morte. Um drama com excelentes atuações de
Sean Penn, Naomi Watts e Benicio Del Toro.

Nos Estados Uni dos. Já que estamos pelos lados de Hollywood, não é que ainda encontramos uma pitada de conteúdo e humor inteligente? É daí que surgem ótimas diversões, como Shrek 2 e Homem-aranha 2, exemplos raros de seqüências que superaram seus originais. Também vale destacar 0 último samurai, que tem a nobre proposta de buscar a cultura oriental sem o típico viés preconceituoso ocidental, além de ter Tom Cruise como um ator de verdade.

Se nomes entram em moda, um deles atualmente é o do roteirista Charlie Kaufman. Ele é, hoje, muito mais autor do que qualquer diretor. Seus roteiros estão em elevado prestígio, principalmente depois de Adaptação. N este, el e escreveu sobre o bloqueio criativo de um roteirista erudito, chamado Charlie Kaufman (?!), além de criar um irmão gêmeo, também roteirista, adepto das fórmulas chavões hollywoodianas. Depois disso, o que mais esperar de uma mente dessas? Pois bem, nos brindou com Brilho eterno de uma mente sem lembranças, com Jim Carrey num de seus papéis sérios. Só a sinopse é de dar água na boca: homem desco- bre que sua namorada apagou tudo ligado a ele da memória por meio de uma empresa chamada Lacuna. Atordoado, ele procura a empresa para fazer o mesmo, mas sua consciência parece não querer ser apagada.

Filmes perturbadores e polêmicos parecem ser a especialidade do dinamarquês Lars von Trier. Depois de Dançando no escuro, pôs à prova seu teatro filmado de Dogville. Falado em inglês e ambientado durante a Grande Depressão americana dos anos 30, tem Nicole Kidman como a refugiada que encontra abrigo na pequena Dogville. Do carinho e amor do início, seus moradores passam a abusar dela em trabalhos manuais e até sexuais. A condição humana mais mesquinha e hipócrita está em cada detalhe dos moradores. D ogville écinema de alta tensão, com final apoteótico e libertador, ao contrário de Dançando no escuro.

Pensando bem, $10 \%$ do que chega aos cinemas são aproximadamente 25 filmes, o que dá a média de dois filmes por mês. E quem vai mais de duas vezes ao cinema por mês com o ingresso a 15 reais? Poucos. A questão passa a ser saber escolher qual filme ver. Encare um prato nacional sem marketing, abra a mente para um europeu mais ousado, sem esquecer dos bons diretores americanos que ainda persistem. Você terá chances de acertar e, assim, fará com que o gosto pelo bom sabor do cinema permaneça...

\footnotetext{
Lucas Rodrigues Pires

Colunista do Digestivo Cultural

E-mail: lucpires@uol.com.br
} 